\title{
Oral History Project: Lithuanian Students Study the Past to Gain Skills for the Future
}

\author{
Bobbi Carolyn Hansen ${ }^{1, *}$ \\ ${ }^{1}$ Department of Learning and Teaching, University of San Diego, USA \\ *Correspondence: Department of Learning and Teaching, University of San Diego, USA. \\ E-mail: chansen@sandiego.edu
}

Received: August 26, 2014 Accepted: September 18, 2014 Published: September 26, 2014

doi:10.5296/ije.v6i3.6229 URL: http://dx.doi.org/10.5296/ije.v6i3.6229

\begin{abstract}
This paper focuses attention on international school reforms that position students to gain critical $21^{\text {st }}$ century work skills such as critical thinking, communication, collaboration and creativity. Special attention is given to a category of instructional methodologies known as project-based learning (PBL). PBL aptly teaches standards-based curriculum while also challenging students to inquire, make decisions and communicate with others as they work collaboratively to complete a project. PBL comes in many forms from problem-based, more centered on student thinking processes, to activity-based, making a product, and, finally, place-based, which is generally focused in the community. This paper addresses the latter kind as it involves an Oral History community project in a Lithuanian secondary school. This particular project was selected, not only to showcase the many benefits of PBL, but also to highlight $21^{\text {st }}$ century skills that students gained while working on the project. As the paper makes a case for incorporating 21 st century skills into international school reforms, it also hopes to inspire other educators who may wish to consider incorporating PBL pedagogies in their own schools.
\end{abstract}

Keywords: project-based learning, oral history, $21^{\text {st }}$ century skills, Lithuania 


\section{Introduction}

At the present time forward-thinking nations are immersed in school reforms that will hopefully position their youngest citizens for success in the workplace of the 21 st century. These nations have come to appreciate that the skills students mastered in the past are not, necessarily, sufficient to serve them in the coming decades. "With manufacturing and other low-skill tasks in the services sector becoming increasingly automated, the need for routine cognitive and craft skills is declining, while the demand for information-processing skills and other high level cognitive and interpersonal skills is growing," so asserts international experts in the report, OECD Skills Outlook 2013: First Results from the Survey of Adult Skills. This report is one of the first international assessments that identified workplace skills needed to respond successfully to the challenges of a rapidly changing global labor market. The most successful nations have been the ones that have chosen to adapt their school systems to support these changes.

However, as the developed world transitions from one pivotal age to the next, many of the world's school systems are still tethered to old behaviors and methods. In the Industrial Age, characterized by workers laboring in factories having little or no input into how their job should or could be performed, schools provided an education where students were taught to follow the rules and not to question authority nor think for themselves. Now, in the so-named Post-Industrial, or Knowledge-Age, workers need an entirely different skill-set, one that will mirror the needs of the global marketplace. Yes, competence in the basics, or what has been termed, the 3 Rs, reading, (w)riting and (a)'rithmetic, is still needed, along with foundational subject-matter knowledge. However, today's jobs will require workers to do things with this knowledge and to use it to create new knowledge, so says Tony Wagner, author The Global Achievement Gap: Why Even Our Best Schools Don't Teach the New Survival Skills Our Children Need-and What We Can Do About It (2008). Wagner details the new skills that are demanded by the workplace:

- to locate, assess, and represent new information quickly.

- to communicate this to others,

- to work productively in collaborations with others.

- to be able to understand things at a 'systems' or big picture' level.

- to be adaptable, creative, and be able to learn for themselves

Having students attain these skills requires a nation's full commitment to embrace new ways of learning. Therefore, the primary goal of the current article will be to showcase one nation's model school project that has successfully incorporated $21^{\text {st }}$ Century skills. The Lithuanian Oral History project hopefully will serve to inspire other educators who may be considering such programs in their own countries or communities.

First, however, in an effort to provide the reader with a foundation with which to better understand the project, the paper will present the following two background information pieces, (1) the need for students to gain $21^{\text {st }}$ Century skills, and, (2) the ability of project- 
based learning, and particularly, oral history projects, to serve as a powerful vehicle for students' acquiring of such skills.

\section{Literature Review}

\subsection{The Importance of $21^{\text {st }}$ Century Skills}

As previously discussed, much interest has emerged, worldwide, in the notion of $21^{\text {st }}$ century skills and international organizations have been spawned to support such change efforts. In the US, the Partnership for 21st Century Skills, a coalition of business and education professionals, has identified four learning and innovation categories that students will need: They are:

- Critical Thinking and Problem Solving-It can be said that everyone-from the hourly worker to those in the highest echelons of power-needs to be able to reason analytically and to solve problems. "Most effective educators... provide students with opportunities to use knowledge meaningfully by developing high-order thinking and problem solving skills and connecting knowledge to real-world applications," (Hardiman, 2003).

- Communication-Effectively communicating with others takes primacy in the global job market. Proficiency in the communication arts--speaking, listening, writing--is mandatory as workers today are called upon to transmit information in both formal and informal settings to colleagues in the next office or across the planet. Communication skills are learned by actually communicating - not by being lectured to nor from a textbook. Moreover, in most nations' classrooms, student discourse is limited and is used more to check comprehension rather than to develop competence (Fisher, Frey \& Rothenberg, 2008).

- Collaboration skills, experts agree, will be needed in the workplace as we join with others to complete tasks. In spite of this argument, the fact is that students in most of the world's classrooms spend the majority of time working either in isolation or in whole class recitation exercises. There exists an extensive body of research indicating that students who engage in cooperative learning learn significantly more, remember it longer, and develop better critical-thinking skills than their counterparts in traditional lecture classes (Marzano, et al, 2001).

- Creativity and Innovation. While the other skills we have discussed (critical thinking, communication and collaboration) have a common-sense aspect regarding their usefulness in 21 st century jobs, some have questioned the role of creativity as not being as essential. However, as opposed to workers in the Industrial Age, experts have asserted that virtually all adults in the Knowledge-Age will need to employ original thinking to solve problems and innovate in the workplace (Ashbury \& Rich, 2008).

$21^{\text {st }}$ century skills have also gained the attention of several United Nations Educational, Scientific and Cultural Organization (UNESCO) initiatives and conferences. One, in Vilnius, 
Lithuania in December, 2013 was organized by the UNESCO Institute for Lifelong Learning (UIL), the Directorate-General for Education, and Culture of the European Commission (DG EAC) and the framework of the Lithuanian Presidency of the European Union. The conference's aim was to ensure that all adults have access to relevant and high quality learning opportunities throughout their lives. A similar UNESCO sponsored conference, the International Forum Assessment \& Teaching of 21st-Century Skills, was held this year in Costa Rica with the goal of "encouraging school systems to incorporate these skills in their teaching and learning programs so that they can prepare the students to achieve academic success and fulfillment in the workplace and in life in general." (UNESCO, 2014).

\subsection{Project-based Learning: A Global $21^{\text {st }}$ Century Pedagogy}

Project-based learning (PBL) has captured the world's attention as it is emerging as a powerful pedagogy for teaching these critical $21^{\text {st }}$ century skills. For example, UNESCO has solidly embraced project-based learning as one way to upgrade students' skills to meet the growing needs of the global marketplace and has showcased several examples of noteworthy PBL projects on their website: (1) Project-based learning and ICT, (2) Project-based learning: Educational Community, (3) Making real-world connections through project-based learning and telecollaboration.

The research base for PBL is strong and includes studies originating in many nations. When project-based learning is compared with learning outcomes for students taught through traditional methods, studies demonstrate PBL can increase long-term retention of content, help students perform as well as or better on high-stakes tests, improve problem-solving and collaboration skills, and improve students' attitudes towards learning (Acar, G., 2013; Strobel \& van Barneveld, 2009; Walker \& Leary, 2009, Mergendoller, J.R., Maxwell, N.L., \& Bellisimo, Y., 2006).

While not a new pedagogy, PBL has experienced a renaissance in classrooms around the globe. As far back as the early 1900s, John Dewey advocated for classrooms to be filled with projects as a way for students to "learn by doing". And, Kilpatrick believed that projects allowed for "whole-heartedness of purpose" (1918, p. 319). According to Markham et al, (2003) project-based learning is a teaching approach with the goal of having students gain real world knowledge and skills by investigating a question or problem. Markham goes on to describe the essential elements of PBL. They are:

- Significant Content -At its core, the project is focused on teaching students important knowledge and skills, derived from standards and key concepts at the heart of academic subjects.

- 21st Century Competencies -Students build competencies valuable for today's world, such as problem solving, critical thinking, collaboration, communication, and creativity/innovation, which are explicitly taught and assessed.

- In-Depth Inquiry - Students are engaged in an extended, rigorous process of asking questions, using resources, and developing answers. 


\section{Macrothink}

- Driving Question - Project work is focused by an open-ended question that students understand and find intriguing, which captures their task or frames their exploration.

- Need to Know - Students see the need to gain knowledge, understand concepts, and apply skills in order to answer the Driving Question and create project products, beginning with an Entry Event that generates interest and curiosity.

- Voice and Choice - Students are allowed to make some choices about the products to be created, how they work, and how they use their time, guided by the teacher and depending on age level and PBL experience.

- Critique and Revision - The project includes processes for students to give and receive feedback on the quality of their work, leading them to make revisions or conduct further inquiry.

- Public Audience - Students present their work to an audience, beyond their own classmates and teacher.

\section{The Lithuanian Oral History Project}

The next part of this paper will describe an oral history project in one high school in Lithuania. To provide the reader with important background information the author will provide an historical framework of the project.

\subsection{Historical Background}

Since Lithuania's independence from the former Soviet Union in 1990 and subsequent membership in the European Union in 2004, there became an urgent need for students to gain skills that will serve them in the world marketplace-skills such as the 4Cs as described earlier in this paper. Teachers, the world over, desire to make a difference in the lives of their students. The teachers at our target school are no exception. They, along with many teachers and administrators from schools in Lithuania, have volunteered as participants in workshops sponsored by the American Professional Partnership for Lithuanian Education (A.P.P.L.E.). Founded in 1990, A.P.P.L.E. has transported American educators to Lithuania in the summer months to lead teacher development efforts and expose educators to 21 st century pedagogies. The A.P.P.L.E. organization's mission was to counter what Juceviceniene (2005) noted as an overreliance on post-soviet pedagogies. "In the context of Lithuanian education today, the emphasis on rote learning over critical thinking skills - characteristic of education under the former socialist system-persists, making it more difficult for Lithuania to emulate the modern European model of education" (p. 14). However, Juceviceniene (2005) goes on to note that this situation is improving, as Lithuanian students recently have great improvements as compared to students from other post-soviet nations (p. 14).

The current article focuses on a school in Prienu, Lithuania. Ziburys Gymnasim (high school), a recent recipient of one of Lithuania's national awards for best practices, was chosen specifically for its visionary leadership, openness to innovation, and highly competent teaching staff. Moreover, project-based learning had already been embraced by the 
administration and teachers as a conduit to help students gain critical 21 st century skills. "Teachers decided upon using oral history as the project organizer, because it allows students to be active, not passive as they engage with learning about their national heritage through the stories of their elders," asserts Irma Sneideriene, Headmistress of Ziburys Gymnasim. Ms. Sneideriene has been a collaborative partner with the University of San Diego (USD) through the work of Nancy Hanssen a clinical faculty member at USD and a long-time volunteer instructor and board member for A.P.P.L.E. In 2007, 2009 and 2011, University of San Diego students traveled with Hanssen to Lithuania to visit schools and work with children at Vilijampole's Children and Youth Boarding Home in Kaunas as part of a required course for the teaching credential program. Through private donations, she was able to arrange for Ms. Sneideriene to meet with faculty at USD and visit schools in southern California. The university has continued this partnership with the launching last summer of an Oral History project where Irma is now the headmistress.

Time periods in Lithuanian history on which the Oral history project was based were recommended by the support teachers. They included, (1) 1939-1945, (2) 1945-1990, and, (3) 1990 to present. According to Vilija Juodsnukiene, one of the project's teachers and an expert in Lithuanian history, these time periods were chosen for the following reasons:

- Time period 1-1939-1945: The Second World War began in 1939, when Germany invaded Poland. Lithuania was still an independent nation. Back then, Lithuania and its neighbors' fate were determined by the Molotov - Ribbentrop Pact, an agreement between Germany and the Soviet Union. The two aggressive states divided the spheres of influence in Eastern Europe. Already during the war, on June 15, 1940, due to its favorable international situation, the Soviet Union occupied Lithuania. At the beginning of the Soviet - German War in 1941, while attacking the Soviet Union, Germany occupied Lithuania. At the time, Germany carried out the Holocaust throughout all Europe. Some Lithuanians even risked their lives to save Jews. During the war, the life of the people living in the occupied territories was very difficult. The war crushed the fates of people. Families were separated and many children were orphaned. Despite all the difficulties, at all times there appeared some good people, even strangers, who would feed and shelter the orphans. As the Soviets were attacking and the Germans retreating there were some battles taking place in Lithuania, which affected a lot of people.

- Time Period 2- 1945-1990: After World War II, Lithuania was occupied by the Soviet Union again. The life of the people was very hard, since food and essential products were scarce. The Lithuanians did not want to recognize the Soviet government and many of the men went into the woods to fight the invaders as partisans. A guerrilla war lasted from 1944 to 1953. During the war, Lithuanians, who supported the partisans or did not join the collective farms, or otherwise did not suit the Soviet government, were forcibly deported to the remote areas of the Soviet Union - Siberia and Kazakhstan. Among them were many women and children. A total of 20,000 partisans and their supporters were killed during the war. Communist propaganda proclaimed that all people in the Soviet Union were equal, but they were not. The 
society consisted of different layers. At the very top were the officials of the Communist Party and other people close to the government. According to the communist ideology, salaries were paid. For example, a driver who used to deliver nomenclature earned more than a doctor or a teacher. Also, each young man had to serve two years in the Soviet army. All the private property was abolished, so that even in rural areas people who were engaged in agriculture could only have a small private farm, one cow, 60 acres of land, and so on. The government identified low prices for the essential products - bread, cereals, pasta, milk, vegetables - and services, including the municipal tax rates. People did not starve. Nevertheless, there was no unemployment in the country, so all people had enough work. In the rural areas people worked on collective farms. Besides, there was no free press, the newspapers wrote about what was beneficial to the government only. At the time one of the biggest attractions was going to the cinema, dances were held in the culture house as well. In the Soviet period, people ignored the household deprivation, instead they invented different kinds of entertainment, raised families and enjoyed a private life.

- Time Period 3-1990-present: Lithuania was part of the Soviet Union for 50 years, but the idea of its restoration did not disappear. The end of the last decade of the twentieth century is known as the national Movement of the period - 'Sajūdis'. As soon as the circumstances were favorable, Lithuanian people determined to peacefully withdraw from the Soviet Union. In 1990, March 11 the lawfully elected government of Lithuania declared the restoration of an independent Lithuanian state. Even so, the Soviet leadership still tried to force the people to abandon their independence (such as trying to organize an economic blockade). However, thousands of people defied the Soviet intimidation and defended their and their children's freedom.

\subsection{The Project Begins}

As previously discussed, the Oral History Project involved teachers and their students at Ziburys Gymnasim in Prienai, Lithuania. Headmistress Sneideriene took the lead and ushered in the project through the 2013-2014 school year along with two talented and dedicated teachers, Vilija Gustaityte, an English teacher, and Vilija Juodsnukiene, a history teacher. "A final culminating product of a published book, will be produced by students," comments Nancy Hanssen, USD liaison and project facilitator. Giving some additional background, Ms. Hanssen notes that the Oral History project was modeled after another one of USD's partner schools, Daraja Academy, the first secondary school for girls in Kenya, Africa. There, Dr. Heather Lattimer, Department Chair, introduced the project to teachers with the purpose of modeling Project-Based Learning as an instructional methodology.

What Is an Oral History? An oral history is "a collection of an individual's thoughts and recollections about his or her past," emphasizes Huerta \& Flemmer, (2000). As a tradition to pass along an indigenous culture's heritage, oral history has been practiced for thousands of years. "The Greek historian Herodotus used interviews extensively in his writings." (Huerta \& Flemmer, 2000, p. 110). Oral history is a versatile classroom tool for expanding students' understanding of events, and periods in history through the perspectives of those who lived 
them helping history come alive for students. (Crocco, 1998). Oral history projects share all of the aforementioned advantages of PBL as well as others:

- High student engagement for learning history: As a teaching method, educators have noticed that $\mathrm{OH}$ keeps students engaged. Project-based, oral history research is "a powerful antidote to students' frequent apathy toward textbook studies of history," (Sitton, 1983, p. 3)

- Allows for analysis of social problems: "By promoting creative use of oral history projects, we can help our students explore community life, analyze social problems, and consider possible solutions," (Huerta \& Flemmer, 2000, p. 111).

- Promotes national pride: It is a national priority that around the globe all countries teach students about their own nation's history. In addition to being a matter of national pride, knowing one's history prepares a nation's youth to live and work productively in that society.

- Helps shape personal identities: Young people in every country and every walk of life begin to form their identities through their families, communities, religions and other affiliations. Learning from elders about the history of one's country is a most powerful experience that won't soon be forgotten.

\subsection{Phases of the Project}

Because conducting an oral history project requires the integration of many interconnecting components, it is best to launch the project in distinct phases. To assist others in the global community who may be considering replicating Oral History projects in their schools, detailed descriptions of each of the phases follows, along with the identification of the instructional practices that afford students practice in essential 21 st century skills.

\subsubsection{Phase 1: Summer 2013}

The summer regional in the lovely resort town of Prienai looked a bit different last summer. Students, still in school, were busy with final tests, end of the year activities and launching, along with their teachers, an oral history project spanning the 2013-2014 school year. Capitalizing on the experiences at Daraja, the Lithuanian oral history project was launched through a joint Skype session, arranged by Nancy Hanssen, which included teachers and students in both Kenya and Piruna.

Following that $21^{\text {st }}$ century telecollaboration experience, Headmistress Sneideriene organized a workshop for students and their teachers that focused on key oral history skills, interviewing, note taking, using technology, peer collaboration and finally, writing and synthesizing the notes into the final narrative. Students were invited to identify three family and/or community members from three different time periods to interview over their summer break. Questions were brainstormed and grouped into categories of personal life, community life and political life and included the following examples of each. Because this project intended to increase students' mastery of $21^{\text {st }}$ century skills, these connections will be also highlighted. 


\section{Personal}

What was your childhood like?

Did you celebrate any particular event when you became an adult?

Describe your marriage ceremony?

\section{Community Life}

How has this community changed over the past fifty years?

How has the role of the elders in the community changed?

How has education changed?

\section{Political}

What was life like under Soviet rule?

What do you remember about the struggle for independence?

How has life changed since independence?

\section{General Questions}

What were the best experiences in your life? Why?

What were the hardest experiences in your life? Why?

Who has been the biggest influence on your life? Why?

\section{Phase 1 instructional practices linked to $21^{\text {st }}$ century skills included:}

- Building background knowledge using project from Kenya as a model (critical thinking, creativity)

- Discussing the challenges and success of the project by Skyping with students in Kenya (critical thinking, communication)

- Creating list of possible interview questions in small groups (collaboration, communication, creativity)

- Practicing interviews with teachers and peers (communication)

\subsubsection{Phase 2: Fall 2013}

Students worked with teachers and peers to transcribe the oral interviews they had completed during the summer. Concurrent to this process, students were given opportunities to round out their knowledge of Lithuanian history from teachers and textbooks. Some examples of the stories as told to the students' are highlighted below:

"The most memorable event was January $13^{\text {th }} 1991$. At the time I was 25 . After hearing the news that Soviet Union soldiers were already close to the TV tower, the entire family wanted to be there, together with all other Lithuanians. The atmosphere was full of unity in there.... 
After learning that the tanks had retreated, I felt relieved... like a new-born.”

"Among the bleak days there were a few happier times such as tasting ice cream for the first time in Prienai, a current market place in Liepu Street."

"We were standing in the line of people and singing three songs, but the most memorable one was 'Baltics are Waking Up: Lithuania, Latvia, Estonia.' This song sounded in all three languages. Also, the planes were flying over us dropping flowers and we were standing there until dusk. I think, this event has given us a lot. United in the Baltic countries: Lithuania, Latvia and Estonia."

\section{Phase 2 instructional practices consisted of the following:}

- Instruction regarding the stages of the writing process (communication)

- Peer-critique and peer-editing (collaboration, critical thinking)

- Small group and 1-1 conferencing with students during the editing process (communication, collaboration)

- Use of technology: Skype, Google docs, and video-conferencing to support student work (critical thinking, creativity)

\subsubsection{Phase 3: Spring 2014}

During the spring, with much of the hard work of transcribing the oral histories behind them, students began the task of translating the Lithuanian into English as the final book would be published in each language, with each page having Lithuanian on the front side and English on the back side. This phase not only readied the book for publishing, but gave the students much practice in using the English they had learned in classes.

\section{Phase 3 instructional practices included:}

- Synthesize interview notes and write narrative (critical thinking)

- Translate from Lithuanian to English (critical thinking, communication)

- Organize narratives and photos (creativity, critical thinking)

- Work collaboratively to create book lay-out and design (collaboration, creativity)

\subsubsection{Phase 4: Fall 2014-Celebration}

A final phase of PBL is always that of celebration. It should be noted that a celebration is an important component of PBL, and is not a frivolous event. Students and teachers work hard and a shared sense of completion is needed to add closure in much the same way as a workplace team might celebrate and congratulate each other on the success of the completion of a major organizational project.

For the Lithuanian Oral History project a final celebration of the students' work is being planned for early in the 2014-2015 school year. Along with school-wide activities, students, their teachers and Headmistress Sneideriene will be invited to present their final published 
book at a special event at which time members from the Deputy Minister of Education of Lithuania will be in attendance.

\section{Conclusion}

The goal of this paper was to showcase one oral history project conducted in a Lithuanian secondary school and the affect that project had on furthering students' $21^{\text {st }}$ century workplace skills. It is hoped that other nations' educators will be inspired to consider undertaking such a project in their own schools. On that point, it should be noted that Virginija Duksiene, a teacher from Svencionys, a city in southern Lithuania, was so impressed with the high level of learning evidence by the students from Ziburys Gymnasim, that she has committed to continuing the project at her school.

To address the original thesis, to what extent does student proficiency in $21^{\text {st }}$ skills translate into better outcomes for individuals and for nations? Can the nations of the world transform their schools by instituting PBL practices in the schools? Perhaps, at the present time, full implementation of that goal seems a bit lofty. However, a hopeful picture has emerged with a large contingent of schools scattered throughout the world that have moved in the direction of creating authentic curriculum for students, of which oral history projects can be shining examples. "Oral history narratives add to the collective knowledge of local and national history and document our citizens' participation in an event or development." (Huerta, \& Flemmer, 2000, p. 115). Teachers wishing to implement an Oral History project at their school can find readings about methods and models for using oral histories in the classroom at from the Oral History Association home page: http://www.oralhistory.org

After participating in an oral history project, students may understand that history represents more than a series of events from which they are far removed. In the Lithuanian Oral History Project enthusiastic comments from students confirmed this outcome:

"I gained experience in how to prepare for an interview and to come up with the interview questions. Also, how to ask the elders politely so as not to offend a person while questioning about his private life"

"The project helped to gain experience of journalism, such as to interview and then to record."

“ I gained experience in communicating with different people of different ages.”

"The project led to further interest in the history of the past."

"The project aroused interest in the stories of my family, relatives and other close people."

"The project encouraged me to take interest in the history of Prienai region; It was interesting to talk to people you've never met before."

"I had the opportunity to compare the historical events of the period with people's stories."

As one author puts the challenge of history instruction, "the past exists only as we continue to 
bring it alive" (Galt 1992, p. 238). Oral history is an excellent tool for achieving that end.

\section{Acknowledgement}

First, this project would never have been possible were it not for the visionary leadership of Irma Sneideriene, Headmistress of Ziburys Gymnasim. She along with two of her teachers, Vilija Gustaityte and Vilija Juodsnukiene, designed the oral history project with Nancy Hanssen, who facilitated the venture and orchestrated a Skype session with teachers and students at the Daraja Academy, in Kenya.

Second, Dr. Heather Lattimer, Department Chair for Learning and Teaching at the University of San Diego, provided the model for the Oral History project, first initiated at the Daraja Academy in Kenya. The students and teachers from Daraja offered support to the students at Prienu Ziburio Gimnazija via Skype making this a multi-national partnership.

Finally, a special thank you to Dr. Paula Cordeiro, Dean of the School of Leadership and Education Sciences at the University of San Diego. Her standards of excellence and commitment to international education served as an inspiration for this project.

\section{References}

Acar, G. (2013). The effect of project-based learning on students' motivation. International $\begin{array}{llll}\text { Journal Of Academic } \quad \text { Research, } & \text { 82-86. }\end{array}$ http://dx.doi.org/10.7813/2075-4124.2013/5-2/B.11

Crocco, M. (1998). Putting the actors back on stage: Oral history. The Social Studies, 89 (1), 19. http://www.tandfonline.com/doi/abs/10.1080/00377999809599817\#.U_LXHUt0xsA

Dewey, J. (1938, 1963). Experience and education. New York, NY: Collier Books.

Fisher, D., Frey, N., \& Rothenberg, C. (2008). Content-area conversations: how to plan discussion-based lessons for diverse language learners. Association of Supervision and Curriculum Development: Alexandria, VA.

Galt, M. (1992). The story in history. New York: Teachers' and Writers' Collaborative. Hardiman, M.M. (2003). Connecting brain research with effective teaching: The brain-targeted teaching model. Lanham, Maryland: R\&L Education.

Huerta, G., \& Flemmer, L. (2000). Using student generated oral history research in the secondary classroom. The Social Studies, 91(3), 110-115.

Jucevieiene, P. (2005). The evolution of national education and educational thought in Lithuania. European Education, 37(3), 8-19.

Kilpatrick, W. H. (1918). The project method. Teachers College Record, 19, 319-335.

Markham T., Larmer J., \& Ravitz J., (2003). Project based learning handbook: a guide to 
standards focused project based learning for middle and high school teachers. Quinn Essentials Books and Printing, Inc., Hong Kong

Marzano, R., Pickering, D., \& Pollock, J. (2001). Classroom instruction that works. Alexandria, Virginia: Association for Supervision and Curriculum Development.

Mergendoller, J.R., Maxwell, N.L., \& Bellisimo, Y. (2006). The effectiveness of problem-based instruction: A comparative study of instructional methods and student characteristics. Interdisciplinary Journal of Problem Based Learning, 1(2), 49-69.

OECD (2013). The Survey of Adult Skills: Reader's Companion, OECD Publishing.

Partnership for 21st Century Skills. (2007). Partnership for 21st Century Skills Framework. Retrieved November 22, 2008 from http://www.21stcenturyskills.org

Strobel, J., \& van Barneveld, A. (2009). When is PBL more effective? A meta-synthesis of metaanalyses comparing PBL to conventional classrooms. Interdisciplinary Journal of Problem based Learning, 3(1), 44-58. http://docs.lib.purdue.edu/ijpbl/vol3/iss1/4/

UNESCO (retrieved on August, 15, 2014 from https://en.unesco.org/events/equipping-adults-21st-century-joining-forces-action-skills-a nd-competences).

Wagner, T. (2008). The global achievement gap: Why even our best schools don't teach the new survival skills our children need--and what we can do about it. New York: Basic Books. Retrieved August 6, 2014 from http://www.shiftingthinking.org/?page_id=58)

Walker, A., \& Leary, H. (2009). A problem based learning meta analysis: Differences across problem types, implementation types, disciplines, and assessment levels. Interdisciplinary. Journal of Problem-based Learning, 3(1), 12-43. http://docs.lib.purdue.edu/ijpbl/vol3/iss1/3/

\section{Copyright Disclaimer}

Copyright for this article is retained by the author(s), with first publication rights granted to the journal.

This is an open-access article distributed under the terms and conditions of the Creative Commons Attribution license (http://creativecommons.org/licenses/by/3.0/). 